\title{
Detection of nudibranch Chromodoris quadricolor associated microbiome using two
}

\section{DNA extraction methods}

\author{
S.M. Abdelrahman ${ }^{a, b *}$, A.M. Hanora ${ }^{c}$, A.A. Aboseidah ${ }^{b}$, S.G. Desoky ${ }^{b}$, Sh.M. Desoky \\ a School of Earth and Atmospheric Sciences, Georgia Institute of Technology, Atlanta, GA 30332, USA. \\ ${ }^{b}$ Department of Botany and Microbiology, Faculty of Science, Suez University, Suez, Egypt. \\ ${ }^{c}$ Department of Microbiology and Immunology, Faculty of Pharmacy, Suez Canal University, Ismailia, 41522, Egypt.
}

\begin{tabular}{|c|c|}
\hline ARTICLE INFO & ABSTRACT \\
\hline $\begin{array}{l}\text { Article history: } \\
\text { Received } 27 \text { April } 2021 \\
\text { Received in revised form } 25 \text { May } 2021 \\
\text { Accepted } 26 \text { May } 2021 \\
\text { Available online } 1 \text { June } 2021\end{array}$ & $\begin{array}{l}\text { DNA extraction with high quality is critical to all molecular genetic analyses. However, } \\
\text { obtaining DNA from microbes associated with animals is challenging. Despite the } \\
\text { availability of various DNA extraction kits in the markets, no studies were conducted } \\
\text { to date to evaluate their potential for the invertebrates such as nudibranch, one of } \\
\text { Mollusca. This study compared the Quick-DNA Fungal/Bacterial Miniprep Kit and }\end{array}$ \\
\hline $\begin{array}{l}\text { Keywords } \\
\text { DNA extraction; } \\
\text { nudibranchs; } \\
\text { CTAB methods; } \\
\text { Zymo Kit; } \\
\text { Next-generation sequencing. }\end{array}$ & $\begin{array}{l}\text { and skin tissues. The universal bacterial primers } 331 \mathrm{f} \text { and } 797 \mathrm{r} \text { and the animal- } \\
\text { specific primers LCO1490-JJ and HCO2198-JJ were used to amplify the } 16 \mathrm{~S} \text { rRNA } \\
\text { gene and partial mitochondrial cytochrome oxidase I gene using extracted DNA as a } \\
\text { template. The DNA and PCR products' quality and concentration were verified with } \\
\text { agarose gel and Nanodrop, respectively. The two methods' quality assessed using } \\
\text { the deep pyrosequencing of the } 16 \mathrm{~S} \text { rRNA gene in capturing a more diverse } \\
\text { microbiome. The highest yield and purity (over } 1000 \mathrm{ng} / \mu \mathrm{L} \text { ) were obtained with the } \\
\text { CTAB method, while it was not exceeded } 260 \mathrm{ng} / \mu \mathrm{L} \text { with Quick DNA kit and display } \\
\text { high purity. Also, } 16 \mathrm{~S} \text { rRNA community amplicon sequencing revealed that the CTAB } \\
\text { way could catch more diverse bacterial groups. The most efficient method of DNA } \\
\text { extraction was CTAB, as it achieved both high concentration and purity. }\end{array}$ \\
\hline
\end{tabular}

\section{Introduction}

Nudibranchs belong to Mollusca, Gastropoda. Their shell is disappeared after the larval stage and is predominantly brilliantly colored and slow-moving [1]. Even though several microorganisms associated with numerous marine organisms have been broadly studied, the microbial communities associated with nudibranchs are relatively unknown. As molecular biology techniques are developing into more valuable tools for understanding microbial communities and their structure from an ecological perspective, it is imperative to produce pure DNA and overcome the tissue problem that challenges the DNA extraction process [2-6]. In contrast, pure DNA is a base for further molecular genetic analyses [7, 8], like PCR and real-time PCR analysis, next-generation sequencing, cloning, and other genotyping procedures. There are several manual DNA extraction protocols and commercial DNA extraction kits. Manual DNA extraction protocols mainly depend on chloroform and phenol to ensure the complete separation for the organic phase, including the genetic material and the liquid phase, containing the cell debris and other contaminants [9].

\footnotetext{
* Corresponding authors at: Suez University

E-mail addresses: samarmoustafa3030@gmail.com
}

(S.M. Abdelrahman)
Many kits are available nowadays. They differ in isolation technique, type and source of the sample, and quantity, along with the runtime required for each sample, elution volume, the yield of DNA, and possible final applications. These kits mostly rely on DNA purification in the solid phase [10] and are performed using a spin column (under centrifugal force). Compared to conventional methods, some kits result in a fast and efficient purification of DNA, such as the CTAB or Phenol chloroform method. Nudibranchs often possess chemical defenses such as producing lipid and protein-rich mucus to clean their surface shield their epidermis from pathogens [11], the main restriction of the DNA extraction process. It was previously reported that the commercial kits and DNA extraction methods give several results to different animals, cells, and animal tissues. Accordingly, for better results, the extraction methods should be optimized for each tissue [12]. Simultaneously, following the steps with slight modification in the lysis and purification processes will produce sufficient DNA for molecular genetics techniques. This study aimed to evaluate two different methods, the conventional methods CTAB based method and the commercially available kit (Quick-DNA Fungal/Bacterial Miniprep) to extract DNA of $C$. quadricolor tissue. The evaluation of the two methods was based on assessing DNA concentration and their convenience for further molecular applications. 


\section{Materials and Methods}

\subsection{Nudibranch sample collection}

A frozen sample of $C$. quadricolor was used for genomic DNA extraction (Figure 1). In contrast, the sample was collected by SCUBA diving in the Red Sea near EI Tor in Suez, Egypt $\left(28.2278{ }^{\circ} \mathrm{N}, 33.6211^{\circ} \mathrm{E}\right)$ while being preserved in DNA/RNA stabilization buffer and then sent to the laboratory for further genomic studies. The amount of tissue used was $250 \mathrm{mg}$ per sample, four samples for each DNA extraction method.

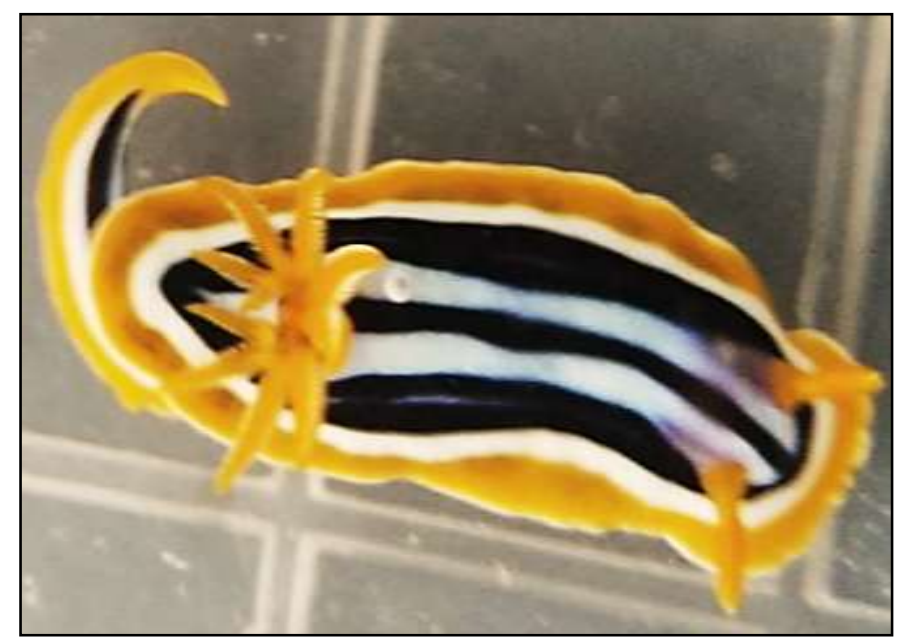

Figure 1. C. quadricolor used in this study

\subsection{Samples preparation}

C. quadricolor sample was stored in DNA/RNA after collecting, then transferred to the laboratory while kept at $-20{ }^{\circ} \mathrm{C}$. Then it was transported to $4{ }^{\circ} \mathrm{C}$ overnight and washed with a new solution of RNA stabilizing solution. The specimen was dried with clean paper towels to remove the excess stabilizing solution. Next, the sample was longitudinally cut into two parts, and each one was separated into the skin and gut with a sterile razor blade. Then the tissues were homogenized in liquid nitrogen.

\subsection{DNA extraction}

\subsubsection{Fungal/Bacterial Miniprep Kit (Zymo Research,} Irvine, CA, USA)

The DNA extraction of $C$. quadricolor was performed using Fungal/Bacterial Miniprep Kit following the manufacturer's instructions, designed to isolate DNA from challenging microorganisms cells, such as yeast, filamentous fungi, gram-positive and gram-negative bacteria that need to be lysis. Zymo kit combines a ZR BashingBead $^{\mathrm{TM}}$ Lysis technology without using organic denaturants or proteinases with Zymo-Spin ${ }^{\mathrm{TM}}$ Technology. The time spent in this method was about 30 mins for four samples. The only modified step was performing tissue lysis with liquid nitrogen to improve the digestion process. Then DNA extraction carried out using $250 \mathrm{mg}$ per animal part; following the manufacturer's instructions briefly, 250 $\mathrm{mg}$ was added to the lysis tube gather with $750 \mu \mathrm{L}$ of BashingBead ${ }^{\mathrm{TM}}$ Buffer, then vortex at maximum speed for 10 mins, the cell debris was removed with a centrifuge at $10000 \mathrm{xg}$ for $1 \mathrm{~min}$. Then purification and washing steps using two types of spin tubes and washing buffers with several centrifugation steps followed by the final elution step.

\subsubsection{Cetyltrimethyl ammonium bromide (CTAB) based method}

The C-TAB protocol isolated the $C$. quadricolor DNA with a slight modification [13]. The homogenized samples were mixed with a preheated digestion buffer that consisted of $20 \mu \mathrm{L}$ Proteinase $\mathrm{K}(20 \mathrm{mg} / \mathrm{mL})$ and $500 \mu \mathrm{L}$ CTAB- $\beta$-mercaptoethanol (1 g CTAB, $0.7 \mathrm{M} \mathrm{NaCl}, 10 \mathrm{mM}$ EDTA, $50 \mathrm{mM}$ Tris- $\mathrm{HCl} \mathrm{pH} 8.0$, and $100 \mu \mathrm{L} \beta$ mercaptoethanol) per $50 \mathrm{~mL}$. The samples were incubated on a heat block for 1 hour at $60^{\circ} \mathrm{C}$ with inverting the tubes every 15 mins. ZR BashingBead was added to samples and vortexed for five min at maximum speed to increase the sample homogeneity. The mixtures were then incubated for 30 mins to allow the sample to settle down. Each mixture was then transferred to a clean tube with adding $5 \mu \mathrm{L}$ RNase $A(20 \mathrm{mg} / \mathrm{mL})$ and incubated for 1 hour at $60^{\circ} \mathrm{C}$ while shaking. The samples were centrifuged at $14,000 \times \mathrm{g}$ for $90 \mathrm{sec}$. Subsequently, $500 \mu \mathrm{L}$ of chloroform: isoamyl alcohol (24:1) was combined with the sample and mixed by inversion then vortexed for $10 \mathrm{~min}$ at low speed. Again samples were centrifuged at $14,000 \times g$ for five min, and the upper phase poured into a new tube, and $500 \mu \mathrm{L}$ isopropanol was combined and mixed by inverting the tubes ten times. After centrifugation for $20 \mathrm{~min}$ at $18,000 \times \mathrm{g}$ at four ${ }^{\circ} \mathrm{C}$, the liquid is pipetted out, and $1 \mathrm{~mL}$ of $70 \%$ ethanol is added to wash the pellets and invert for $5 \mathrm{~min}$. Then the pellet with ethanol transfers to a Zymo-Spin tube; this step improves the DNA purity. Finally, the sample was centrifuged for $1 \mathrm{~min}$ at $14,000 \times \mathrm{xg}$; the ethanol was removed, and the DNA pellet air-dried was then resuspended in $50 \mu \mathrm{L}$ of nuclease-free water. A portion of the isolated DNA was visualized using gel electrophoresis and stored at $-20{ }^{\circ} \mathrm{C}$.

\subsection{DNA spectrophotometric analyses}

The DNA quantity and purity were determined by detecting the absorbance ratio at A260/A280 and A260/A230 using NanoDrop OneC Microvolume UV-Vis Spectrophotometer $w /$ Cuvette (Thermo Fisher Scientific Inc, Wilmington, DE, USA). Typically pure DNA has A260/A280 ratios of 1.8 to 2.0. One $\mu \mathrm{L}$ was poured onto the lower pedestal, then the sampling arm was closed, and spectrophotometric measurement was initiated using the operating software.

\subsection{PCR amplification}

The genomic DNA aliquots were used as a template to amplify two of the most frequently used DNA markers in prokaryotes (16S rRNA) and eukaryotes (Partial mitochondrial cytochrome oxidase I).

The genomic DNA aliquots were used as a template to amplify two of the most frequently used DNA markers in prokaryotes (16S rRNA) and eukaryotes (Partial mitochondrial cytochrome oxidase I). The LCO1490-JJ and HCO2198-JJ primers were used to amplify (COI) gene sequences [14]. The universal $331 \mathrm{f}$ and $797 \mathrm{r}$ primers were also utilized to amplify the 16S rRNA gene [15]. 
Table 1: List of existing primers used in this study.

\begin{tabular}{c|c|c|c|c}
\hline Target gene & Primer & Sequence & $\begin{array}{c}\text { Annealin } \\
\text { g TM/Sec }\end{array}$ & $\begin{array}{c}\text { Amplicon } \\
\text { length/bP }\end{array}$ \\
\hline \multirow{2}{*}{ 16S rRNA } & $331 \mathrm{f}$ & TTCTACGGGAGGCAGCAGT & \multirow{2}{*}{5} & 460 \\
\cline { 2 - 3 } & $797 \mathrm{r}$ & GGACTACCAGGGTATCTAATCCTGTT & 5 & \multirow{2}{*}{8} \\
\cline { 2 - 3 } $\mathrm{*}$ COI & LCO1490-JJ & GGTCAACAAATCATAAAGATATTGG & 708 \\
\cline { 2 - 3 } & HCO2198-JJ & TAAACTTCAGGGTGACCAAAAAATCA & 8 & \multirow{2}{*}{} \\
\hline
\end{tabular}

All PCRs were conducted in a $20 \mu \mathrm{L}$ using DNA Polymerase II (Fisher Scientific, Waltham, USA). Each PCR reaction consisted of $10 \mathrm{mM}$ dNTPs (New England Biolabs, USA), DNA Polymerase II Buffer $5 \mu \mathrm{L}, 10 \mathrm{pmol}$ of either primer, $20 \mathrm{mg} / \mathrm{ml} \mathrm{BSA}$, or $1 \mathrm{u}$ DNA polymerase II. All PCR reactions have an initial denaturation step at $98^{\circ} \mathrm{C}$ for $30 \mathrm{sec}$ followed by 34 cycles, that started with denaturation at $98{ }^{\circ} \mathrm{C}$ for $5 \mathrm{sec}$, then annealing temperature regarding primer sequence (Table1), then extension at $72^{\circ} \mathrm{C}$ for 12 $\mathrm{sec}$, and following with a final extension at $72^{\circ} \mathrm{C}$ for $1 \mathrm{~min}$.

\section{$2.616 \mathrm{~S}$ rRNA community analysis of $C$. quadricolor}

The quality of the extraction methods to access diversity in the microbiome associated with $C$. quadricolor was examined by $16 \mathrm{~S}$ rRNA community analysis and nextgeneration sequencing, whereas bioinformatics analyses and ecological statistics were performed as described previously [16]. The V4 region of 16S rRNA was amplified to prepare Illumina MiSeq libraries using environmental DNA protocol generated by Kozich et al. [17]. Briefly, the Platinum ${ }^{8}$ PCR SuperMix was used to generate V4 amplicons with primers 515F and 806R appended with Illumina-specific adapters [18].

\subsection{Agarose gel electrophoresis}

Verification of genomic DNA and amplified sequences was performed using agarose gel with 1 and $1.5 \%$ agarose (Biobasic inc., Canada), 1X TAE, DNA gel stain GreenView TM $1 \mathrm{ml}$ (GeneCopoeia TM, USA) and $5 \mu \mathrm{l}$ of $50 \mathrm{bp}-10 \mathrm{~Kb}$ DNA Ladder (Hi-Lo DNA) (Minnesota Molecular, Minnesota, USA), or $5 \mu \mathrm{l}$ of $250 \mathrm{bp}-10 \mathrm{~Kb}$ DNA Ladder (GoldBio, Missouri, USA).

\section{Results and discussion}

The present study aimed to evaluate and compare two available methods to extract the microbiome DNA associated with $C$. quadricolor, which may be difficult due to the high protein content in animal tissues and the diversity of the microbiome, which requires different methods of isolating the DNA that depending on the composition of the bacterial cell walls. We used the Fungal/Bacterial Miniprep Kit, based on ZR BashingBead ${ }^{\mathrm{TM}}$ Lysis and Zymo-Spin ${ }^{\mathrm{TM}}$ technology containing five reagents with various functions during extraction; cell digestion, membrane washing, and DNA elution.

The CTAB-based manual method has been used to extract DNA from marine invertebrates [13] with a modification to reduce contaminants and boost the DNA purity of Balanus sp. [19]. Even though all presently published techniques have proved their efficacy in isolation of DNA convenient for PCR amplification or restricting digestion, they need long incubations, numerous precipitation procedures, and washing with ethanol to produce efficient genomic DNA with high purity [17]. These further modifications decrease the overall product and might fail to extract large amounts of high-quality DNA [20]. Our modification in the lysis step with liquid nitrogen and purification using Zymo-Spin ${ }^{\mathrm{TM}}$ technology improves the DNA concentration and purity by decreasing time, unlike other previous changes.

\subsection{DNA quality and quantity measurement}

Both the agarose gel electrophoresis and the spectrophotometer Nanodrop were used for assessing the DNA characters. The visualized DNA aliquots on agarose gel are shown in Figure 2. The Nanodrop is helpful for the detection of impurities such as carbohydrates, proteins, and salts that can suppress and intercept DNA usage in molecular genetic analyses. Typically, high purity DNA has A260/A280 ratios of 1.8. The overall DNA yield in the CTAB-based method was in a 400-1100 ng sample for conducting many PCR reactions. In comparison, the DNA obtained from the Fungal/Bacterial Miniprep Kit was 15-250 $\mathrm{ng}$, per $250 \mathrm{mg}$ of animal homogenized material (Table 2). The DNA absorption was determined at A $260 / 280$ to be in

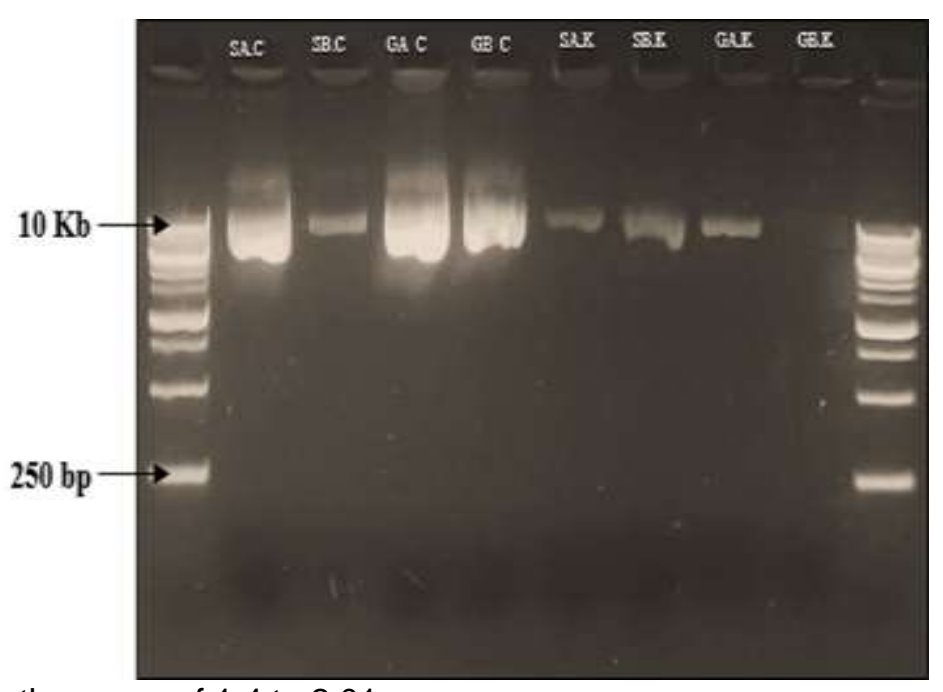

the range of 1.4 to 2.01 .

Figure 2. Gel electrophoresis of total genomic DNA of $C$. quadricolor tissues, and $1 \mathrm{~Kb}$ DNA ladder, Goldbio. GA.K= Gut-A-Kit, GB.K= Gut-B-Kit, SA.K= Skin-A-Kit, SB.K= SkinB-Kit, GA.C= Gut-A-CTAB, GB.C= Gut-B-CTAB, SA.C= Skin-A-CTAB, SB.K= Skin-B-CTAB, and ng.con= negative control. 
Table 2: Summary of DNA concentration and purity for $C$. quadricolor tissues using CTAB method and Zymo Kit.

\begin{tabular}{|c|c|c|c|c|}
\hline \multirow{2}{*}{ C. quadricolor } & \multicolumn{2}{|c|}{ CTAB method } & \multicolumn{2}{|c|}{ Fungal/Bacterial Miniprep Kit } \\
\hline & 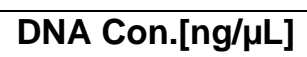 & DNA purity & DNA Con. [ng/ $\mu \mathrm{L}]$ & DNA purity \\
\hline Skin A & 884.1 & 1.86 & 58.7 & 1.78 \\
\hline Skin B & 505 & 1.83 & 234.3 & 1.83 \\
\hline Gut A & 1094 & 2.01 & 77.9 & 1.75 \\
\hline Gut B & 436 & 1.78 & 15 & 1.41 \\
\hline
\end{tabular}

\subsection{Verification of DNA using agarose gel electrophoresis}

Here DNA and PCR products were visualized by 1 and $1.5 \%$ agarose, respectively. Electrophoresis of DNA aliquots extracted with CTAB showed a single band with a huge molecular weight; it also showed no sheared DNA and was not contaminated with RNA. Electrophoresis of DNA aliquots obtained by Zymo kite also showed high purity but low concentration (Fig. 2). It is well known that many factors affect the efficiency of PCR, DNA concentration, and quality, such as the impurities within the reaction mixture, a thermocycler efficiency, optimal temperature for each cycle, quality of PCR chemical constituent, and primers practicality [21]. All DNA extracts obtained with the CTAB method were suitable for amplifying the PCR, and their amplicons were distinguished with a high concentration and purity. However, Zymo Kit's yield was only sufficient for $50 \%$ of the samples with significant differences in concentrations. There were no differences in purity. The 16S rRNA and $\mathrm{COI}$ gene amplicons of $C$. quadricolor DNA were obtained with two techniques shown in (Fig. 3). All CTAB DNA extracts had positive $\mathrm{COI}$ and 16S rRNA amplification, while the DNA extracted with the Zymo kit amplicons were appeared faint or not amplified.

\subsection{The efficiency of DNA extracted with two methods in next-generation sequencing}

We examined the efficiency of the DNA extracted with two methods by community analysis using nextgeneration sequencing of 16S rRNA gene fragments, determined by their efficiency in capturing different microorganism populations. The total microbiome isolated using the CTAB method was 43737 compared to 32269 captured using Zymo Kit (Table 3). The number of structural variations (SVs) differed within C. quadricolor tissues using the extracted DNA by the two methods (Fig.4). Besides, the microbiome isolated by the CTAB extraction method more variable than produced by the Zymo Kit. Also, the number of microbiome sequences present in the DNA of the two methods was more in the DNA extraction with CTAB. Moreover, many classes were only captured by the CTAB method, for instance, Archaea, Actinobacteria, Cytophagales, Rhodospirillales, Sphingomonadales, Betaproteobacteria, and Salinisphaerales.

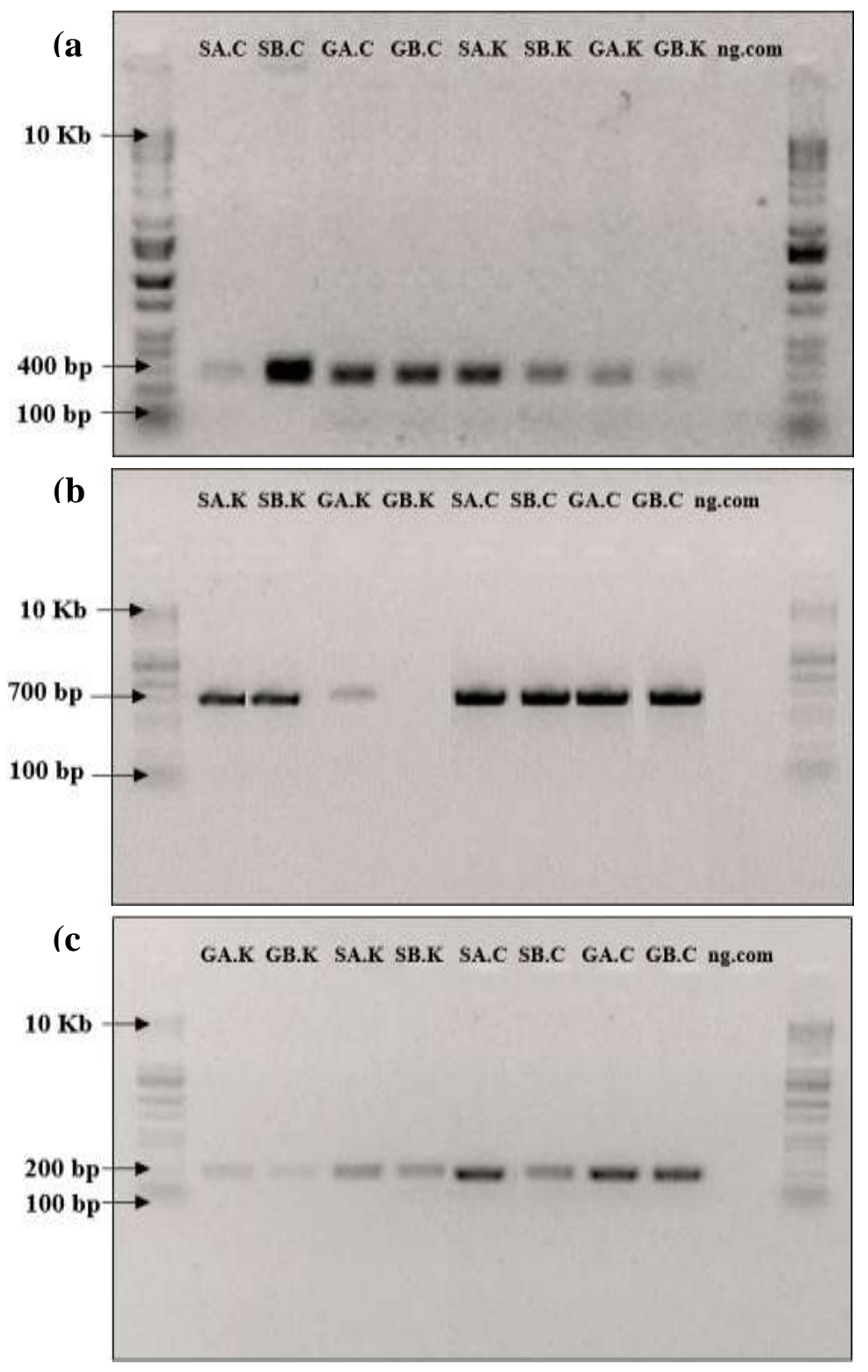

Figure 3. (a) Amplification of the universal 16S rRNA $331 \mathrm{f}$ and $797 \mathrm{r}$ primers, (b) Amplification of (COI) $700 \mathrm{bp}$ on Agarose gel, and (c) Amplification of the universal 16S rRNA $331 \mathrm{f}$ and $797 \mathrm{r}$ primers. Amplification of $16 \mathrm{~S}$ rRNA for community analysis 300 bp. GA.K= Gut-A-Kit, GB.K=GutB-Kit, SA.K= Skin-A-Kit, SB.K=Skin-B-Kit, GA.C= Gut-ACTAB, GB.C= Gut-B-CTAB, SA.C=Skin-A-CTAB, SB.K= Skin-B-CTAB, and ng.con=negative control. $10 \mathrm{kB} \mathrm{HI-LO}$ DNA ladder. 
Table 3: Number of sequences per sample.

\begin{tabular}{|c|c|c|c|c|c|}
\hline \multirow{2}{*}{ Nudibranch } & \multirow{2}{*}{ Animal part } & \multicolumn{2}{|c|}{ Primers } & \multirow{2}{*}{ Instrument code } & \multirow{2}{*}{$\begin{array}{l}\text { Number of } \\
\text { sequences }\end{array}$} \\
\hline & & Forward & Reverse & & \\
\hline C. quadricolor & $\begin{array}{l}\text { - Skin -A (k) } \\
\text { - Skin -B (k) } \\
\text { - Gut-A (k) } \\
\text { - Gut-B (k) } \\
\text { - Skin -A C } \\
\text { - Skin -B ( } \\
\text { - Gut-A ( } \\
\text { - Gut-B @ }\end{array}$ & $\begin{array}{l}\text { SA506 } \\
\text { SA507 } \\
\text { SA507 } \\
\text { SA507 } \\
\text { SA507 } \\
\text { SA507 } \\
\text { SA506 } \\
\text { SA506 }\end{array}$ & $\begin{array}{l}\text { SA704 } \\
\text { SA704 } \\
\text { SA702 } \\
\text { SA702 } \\
\text { SA706 } \\
\text { SA703 } \\
\text { SA710 } \\
\text { SA706 }\end{array}$ & $\begin{array}{c}24 \mathrm{D} \\
14 \mathrm{D} \\
210 I I I \\
12 \mathrm{~A} \\
16 \mathrm{~F} \\
13 \mathrm{C} \\
27 \mathrm{G} \\
26 \mathrm{~F}\end{array}$ & $\begin{array}{c}8384 \\
6680 \\
1414 \\
16791 \\
4060 \\
22034 \\
4755 \\
12921\end{array}$ \\
\hline
\end{tabular}

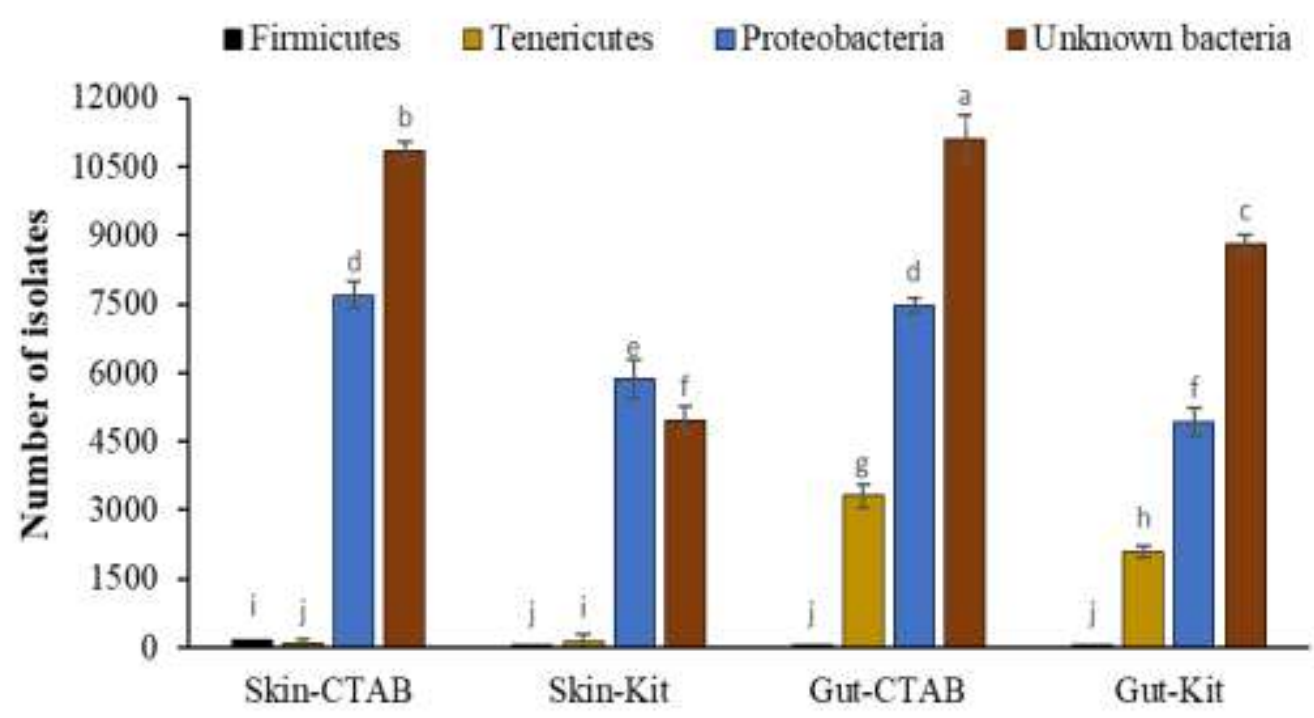

Figure 4. Genomic variations of $C$. quadricolor tissues using DNA extracted by the two methods. Means ( \pm standard error) followed by different letters on the same bars show significant differences according to Fisher's test at $p<$ 0.05 .

The number of sequences and sample variability shows that the CTAB method efficiently isolates the microbiome associated with an invertebrate while demonstrating that the Zymo Kit needs some manipulations to produce more DNA.

Ideally, the protocols of DNA extraction must be quick, efficient, and comfortable to accomplish and obtain sufficient DNA with high quality, appropriate for molecular analysis applications [22]. Traditional techniques such as CTAB commonly take a long time and require poisonous substances [10]. Compared to this, DNA isolation kits have the advantages of limited usage of chemicals, handy methodology, short isolation procedure, and fast results [23]. However, there are some disadvantages to commercial kits, like the high costs of commercial tools. In some studies, the DNA yields and purity are lower than those obtained by conventional methods, as the present study agrees with [23-25].

\section{Conclusions}

Our study used C. quadricolor for DNA extraction, the two used methods gave adequate quality and quantity of DNA for use in the COI and 16S rRNA analyses. The $C T A B$ based method gave the purest product with the lowest level of DNA degradation and contamination. On the other hand, to perform PCR only, relatively small amounts of DNA are required. DNA was also sufficient for other applications, such as high-throughput amplicon sequencing of $16 \mathrm{~S}$ rRNA gene fragments. Based on our findings, CTAB-based methods are also suitable for preparing materials for use in next-generation sequencing-based applications. Moreover, the time required to use toxic chemicals in a CTAB-based process should be ignored, especially when handling challenging samples.

\section{Funding}

The work was propped by The Culture Affairs and Mission Sector, Ministry of Higher Education, and Scientific Research, Egypt. 


\section{References}

[1] Wagele H, Klussmann-Kolb A: Opisthobranchia (Mollusca, Gastropoda) - more than just slimy slugs. Shell reduction and its implications on defence and foraging. Front Zool 2005, 2(1):3.

[2] Surzycki, Stefan: General aspects of DNA isolation and purification. In: Basic Techniques in Molecular Biology. Edited by Surzycki S. Berlin, Heidelberg: Springer Berlin Heidelberg; 2000: 1-32.

[3] Kassem HS, Girolami F, Sanoudou D: Molecular genetics made simple. Glob Cardiol Sci Pract 2012, 2012(1):6-6.

[4] Dairawan M, Shetty PJ: The evolution of DNA extraction methods. American Journal of Biomedical Science \& Research 2020, 8(1):39-45.

[5] Pérez-Brocal V, Magne F, Ruiz-Ruiz S, Ponce CA, Bustamante R, Martin VS, Gutierrez M, Gatti G, Vargas SL, Moya A: Optimized DNA extraction and purification method for characterization of bacterial and fungal communities in lung tissue samples. Scientific Reports 2020, 10(1):17377.

[6] Peñafiel N, Flores DM, Rivero De Aguilar J, Guayasamin JM, Bonaccorso E: A cost-effective protocol for total DNA isolation from animal tissue. Neotropical Biodiversity 2019, 5(1):69-74.

[7] Abdel-Latif A, Osman G: Comparison of three genomic DNA extraction methods to obtain high DNA quality from maize. Plant Methods 2017, 13:1.

[8] Patzold F, Zilli A, Hundsdoerfer AK: Advantages of an easyto-use DNA extraction method for minimal-destructive analysis of collection specimens. PLoS One 2020, 15(7):e0235222.

[9] Butler JM: Chapter 2 - DNA Extraction Methods, Advanced topics in forensic DNA typing: methodology In. San Diego: Academic Press; 2012: 29-47.

[10] Tan SC, Yiap BC: DNA, RNA, and protein extraction: the past and the present. J Biomed Biotechnol 2009, 2009:10.

[11] Wahidullah S, Guo YW, Fakhr IMI, Mollo E: Chemicaldiversity in Opisthobranch Molluscs from scarcely investigated Indo-Pacific areas. In: Molluscs: From Chemoecological Study to Biotechnological Application. Edited by Cimino G, Gavagnin M. Berlin, Heidelberg: Springer Berlin Heidelberg; 2006: 175-198.

[12] Birer C, Tysklind N, Zinger L, Duplais C: Comparative analysis of DNA extraction methods to study the body surface microbiota of insects: A case study with ant cuticular bacteria. Mol Ecol Resour 2017, 17(6):e34-e45.

[13] Panova M, Aronsson H, Cameron RA, Dahl P, Godhe A, Lind U, Ortega-Martinez O, Pereyra R, Tesson SVM, Wrange A-L et al: DNA extraction protocols for whole-genome sequencing in marine organisms. In: Marine Genomics: Methods and Protocols. Edited by Bourlat SJ. New York, NY: Springer New York; 2016: 13-44.
[14] Astrin JJ, Stüben PE: Phylogeny in cryptic weevils: molecules, morphology and new genera of western Palaearctic Cryptorhynchinae (Coleoptera:Curculionidae). Invertebrate Systematics 2008, 22(5).

[15] Chan LL, Mak JW, Ambu S, Chong PY: Identification and ultrastructural characterization of Acanthamoeba bacterial endocytobionts belonging to the Alphaproteobacteria class. PLoS One 2018, 13(10):e0204732.

[16] Abdelrahman SM, Patin NV, Hanora A, Aboseidah A, Desoky S, Desoky SG, Stewart FJ, Lopanik NB: The natural product biosynthetic potential of Red Sea nudibranch microbiomes. PeerJ 2021, 9:e10525.

[17] Kozich JJ, Westcott SL, Baxter NT, Highlander SK, Schloss PD: Development of a Dual-Index Sequencing Strategy and Curation Pipeline for Analyzing Amplicon Sequence Data on the MiSeq Illumina Sequencing Platform. Applied and Environmental Microbiology 2013, 79(17):5112-5120.

[18] Parada AE, Needham DM, Fuhrman JA: Every base matters: assessing small subunit rRNA primers for marine microbiomes with mock communities, time series and global field samples. Environmental microbiology 2016, 18(5):14031414.

[19] Mishra A, Roy U, Kushwaha SK, Lulla S, Prajapati R: Modified CTAB method for high-quality genomic DNA extraction from ship barnacle (Balanus sp.). Indian Journal of Animal Sciences 2019, 89(6):699-701.

[20] Tamari F, Hinkley CS, Ramprashad N: A comparison of DNA extraction methods using Petunia hybrida tissues. J Biomol Tech 2013, 24(3):113-118.

[21] Pipan B, Zupančič M, Blatnik E, Dolničar P, Meglič V, Yildiz F: Comparison of six genomic DNA extraction methods for molecular downstream applications of apple tree (Malus $\mathrm{X}$ domestica). Cogent Food \& Agriculture 2018, 4(1).

[22] Park S-Y, Jang S-H, Oh S-O, Kim JA, Hur J-S: An easy, rapid, and cost-effective method for DNA extraction from various lichen taxa and specimens suitable for analysis of fungal and algal strains. Mycobiology 2014, 42(4):311-316.

[23] Akkurt M: Comparison between modified DNA extraction protocols and commercial isolation kits in grapevine (Vitis vinifera L.). Genet Mol Res 2012, 11(3):2343-2351.

[24] Sousa CC, Gomes SO, Lopes AC, Gomes RL, Britto FB, Lima PS, Valente SE: Comparison of methods to isolate DNA from Caesalpinia ferrea. Genet Mol Res 2014, 13(2):44864493.

[25] Nicolás Oliveira Megal, Revers LF: Developing a rapid, efficient and low cost method for rapid DNA extraction from arthropods. Ciência Rural, Santa Maria 2011, 41(9):15641570. 